\title{
Tendenser i samtida barn- och ungdomslitteraturforskning
}

Futurismens kraftverk, en pojkes hemliga läshunger, barntidningens bortglömda historia - det utgör några smakprov ur föredragen från konferensens första dag som ägnades åt forskningen. Fem presentationer av pågående forskning följdes av en mer allmän diskussion av tendenser och frågeställningar inom den samtida svenska barn- och ungdomslitteraturforskningen. Boel Westin fungerade som moderator under diskussionen.

De fem forskningspresentationerna utgjorde en god illustration av den bredd som $\mathrm{i}$ dag återfinns inom svensk barn- och ungdomslitteraturforskning, både vad gäller ämnen och teoretiska infallsvinklar. Först ut var Janina Orlov, universitetsadjunkt från Stockholms Universitet och Åbo akademi, som berättade om bilden av natur och barndom i den ryska litteraturen med analysexempel både från 1930-talets sovjetiska diktning och samtida rysk litteratur. Från det ryska 1900-talet fördes konferensdeltagarna ett sekel bakåt i tiden då doktorand Anna Grettve vid Uppsala Universitet presenterade sin kommande avhandling om den svenska realistiska barnlitteraturen 18401870. Hon undersöker motiv och teman kring klass- och ståndsmotsättningar samt ståndscirkulation i verk av fyra kvinnliga 1800-talsförfattare. I sin presentation berättade Grettve om barnlitterära skildringar av adelsdöttrar som får bevittna släktens förnedrande sociala deklassering och torparsöner som genom trägna studier lyckas svinga sig uppåt i den sociala hierarkin. Hon drog även paralleller till samtidens vuxenlitteratur och politiska debattklimat där frågor kring klass och social rörlighet var centrala.
Eftermiddagens föredrag inleddes av Wiveca Friman, fil dr och universitetslektor vid Högskolan i Kristianstad, som presenterade sitt forskningsprojekt om den moderna ungdomsromanens genrer, tendenser och genomslagskraft från 1990 och framåt. Projektets syfte är att kartlägga utgivningen av ungdomslitteratur i Sverige, men Friman avser samtidigt att rikta fokus mot vilka genrer som är aktuella under perioden och hur de utvecklas. Särskilt intresse riktades mot debutanternas genrehantering och den nya form av flickbok som hon tyckte sig skönja i 1990-talets bokutgivning. Ett annat förhållningssätt till modern ungdomslitteratur demonstrerades av Helen Asklund, även hon doktorand vid Uppsala Universitet. Inför konferenspubliken redogjorde hon för sin planerade avhandling om flickors och pojkars läsvanor i åttonde klass. Denna innefattar såväl empiriska undersökningar som textanalytiska avsnitt om läsning i för- och grundskolan. I de undersökta klasserna hade Asklund funnit vitt skilda läskulturer, vilket hon tolkade som att det inte finns någon specifik kanon inom skolan. Dessutom konstaterade hon att pojkarna ofta var negativt inställda till läsningen medan flickorna var mer öppna för skilda genrer och för att prata om det de läst. Slutligen berättade Sonja Svensson, docent och fram till första juli 2005, chef för Svenska barnboksinstitutet, om sin planerade kartläggning av svenska barn- och ungdomstidningar 1766-1900. Målsättningen är att skriva en monografi om dessa tidningars historia med inriktning på bland annat genrer, genretypiska karaktäristika och innehållskategorier samt litterära och konstnärliga inslag.

Helen Asklunds avhandling skrivs inom 
projektet "Genusperspektiv på barns och ungdomars läsning i skolan" med säte i Uppsala Universitet. Detta projekt är ett exempel på ett återväckt intresse för pedagogiska problemställningar. Under de senaste åren har forskare börjat uppmärksamma såväl barnlitteraturens roll i skolan som pedagogiska aspekter av den barnlitterära texten på nytt. Denna tendens är både ett tecken på och en följd av den mångfald som i dag återfinns inom området, något som Boel Westin lyfte fram i sin inledningsföreläsning. Att anlägga pedagogiska infallsvinklar på litteraturen är inte längre lika värdeladdat utan det tycks finnas en relativt stor enighet runt att det ofta är svårt att dra en gräns mellan det estetiska och det pedagogiska. Det är en insikt som inte minst det ökande intresset för äldre barnlitteratur iSverige har bidragit till. Med Ulf Boëthius uttryck har det skett en "repedagogisering" av den svenska barnoch ungdomslitteraturforskningen

Trots den större acceptansen för pedagogiska frågeställningar inom barn- och ungdomslitteraturen blev det tydligt att frågan fortfarande väcker känslor. Ulla Lundqvist var den som starkast förespråkade en särhållning av estetiska och pedagogiska angreppsvinklar. Hon menade att den pedagogiska forskningen tillhör en annan disciplin och att forskningen inom litteraturvetenskapen alltid måste ha en estetisk utgångspunkt. Boel Westin däremot ansåg att avståndstagandet från det pedagogiska bör ses som ett steg i barnlitteraturens etableringsprocess. Enligt Westin har barnlitteraturforskningen i Sverige nått en tillräckligt stark ställning för att kunna kombinera det estetiska och det pedagogiska på ett fruktbart sätt. Det är ett fundament för forskningen i sig självt: att öppna den för helt nya angreppsvinklar. Viktigast är att vi har ögonen öppna för olika typer av perspektiv.
Repedagogiseringen kan även ses i ett forskningspolitiskt perspektiv. Lena Kåreland, som leder projektet där bland andra Helen Asklund medverkar, påpekade att det under de senaste åren funnits bidrag att söka för forskning med anknytning till skolan och att det helt enkelt varit taktiskt att lämna in dylika ansökningar. Utan tvekan har det bidragit till en ökning av forskning med pedagogisk inriktning. Björn Sundmark poängterade vidare att repedagogiseringen också hänger ihop med det han kallade för en etisk vändning inom skolan och lärarutbildningen, det vill säga att man tar hänsyn till bland annat de krav på etnisk mångfald som det mångkulturella samhället för med sig. Vid valet av litteratur menade Sundmark att det $i$ dag vägs in andra aspekter än de renodlat estetiska. Man undersöker exempelvis texternas budskap och försöker finna texter där både män och kvinnor samt olika etniciteter finns representerade. Därmed skapas också behov av en forskning som diskuterar dylika aspekter.

Genom den etiska vändningen har en annorlunda typ av litterär kanon skapats där pedagogiska utgångspunkter får en större vikt. Frågan om det finns en barnlitterär kanon och om vi överhuvudtaget vill ha en sådan har väckt mycket debatt under de senaste åren och den fick även stort utrymme i konferensens diskussion. De flesta deltagarna tycktes vara eniga om att det finns behov av en kanon, i synnerhet inom skolan och lärarutbildningen. Däremot fanns det en osäkerhet angående hur denna borde utformas. Trots att klassuppsättningarnas tid är förbi i skolan vill många lärare, enligt Wiveca Friman, ha ett slags kanon som vägledning vid valet av litteratur. Denna bör dock vara bred och inte toppstyrd genom exempelvis ingripanden från staten. Mary Ingemansson menade att en kanon också är vik- 
tig för att ge kunskap om den barnlitterära historien. För att kunna förstå såväl nutiden som nutidens litteratur behöver vi en bas att stå på och en kanon är ett sätt att skapa den.

Kanondebatten handlar som bekant inte bara om vilka böcker vi ger barnen utan även vad vi väljer att forska om. Trots att det finns en relativt stark barnlitterär forskningstradition i Sverige finns det fortfarande många mer eller mindre outforskade områden. Under de senaste tjugo åren har det utförts mycket forskning om litteratur skriven efter 1945, även om det kommer mer forskning om exempelvis det barnlitterära 1800-talet. Maria Nikolajeva påpekade att Sverige därvidlag skiljer sig från många andra länder. I exempelvis USA finns mycket forskning om äldre barnlitteratur, medan nyare texter fått mindre uppmärksamhet. Hon menade också att kanondebatten är olika i olika länder. I USA har man i hög grad gått ifrån kanonbegreppet, medan kanondiskussionen varit livlig i delar av Norden.

Svenska barnboksinstitutets konferens lockade deltagare från de flesta lärosäten i Sverige, men även från flera av de nordiska länderna. Det finns naturligtvis skillnader vad gäller forskningsinriktningar och möjligheter att ägna sig åt barn- och ungdomslitteraturforskning. I Sverige har barn- och ungdomslitteraturforskningen tveklöst en stark institutionell ställning idag. Två betydelsefulla och forskningsfrämjande etableringar är Center før børnelitteratur vid Pedagogiska Universitetet i Köpenhamn och det nu avslutade projektet"Children's Literature Pure and Applied" vid Åbo Akademi. Men den danska forskningen befinner sig till exempel, som Anna Karlskov Skyggebjerg påpekade, i en annan fas. Medan barnlitteraturforskare i Sverige och Norge börjat återupptäcka det pedagogiska perspektivet befinner sig Danmark i en avpedagogisering. Den danska barn- och ungdomslitteraturforskningen har alltså, med Boel Westins ord, ännu inte institutionaliseras. Men att det finns ett stort intresse för forskning runt barn- och ungdomslitteratur runt om i Norden utgjorde den breda uppslutningen och livliga diskussionen på konferensen ett bevis på.

Maria Andersson Elina Druker

\section{Barntidningar - fanns dom? eller - här finns mycket att göra!}

Vad har månne Göte Klingberg, Ingrid Sjöstrand, Elin Wägner, Jules Verne, William Faulkner och ett oräkneligt antal andra kulturpersonligheter och författare gemensamt? Jo, de debuterade i barntidningar. Hur många som, i likhet med August Strindberg, Ivar Lo-Johansson och makarna Bo och Margareta Strömstedt, i späda år stolta prenumererat på en egen tidning kan inte rekonstrueras. Närmast omöjligt är det också att överblicka alla etablerade barnboksförfattares och konstnärers alster som gömmer sig $\mathrm{i}$ tidskrifter. Att detta medium är värt vårt intresse är med andra ord uppenbart.

Det är alltså inte bara så som jag tidigare konstaterat att barnböcker finns, trots att många i det längsta undviker att identifiera dem såsom anpassade för just barn. Ett stort antal barntidningar fanns och har funnits i Sverige liksom - vågar man påstå - i alla 